\title{
Efficacy and limitations of Triticale as a nitrogen catch crop in a mediterranean environment
}

\author{
M. Ângelo Rodrigues ${ }^{\mathrm{a}, *}$, João Coutinho ${ }^{\mathrm{b}}$, Fernando Martins ${ }^{\mathrm{b}}$ \\ a Escola Superior Agrária, Campus de Santa Apolónia, ap. 172, 5301-854 Bragança, Portugal

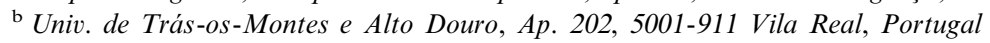

\begin{abstract}
During 3 consecutive years (1996/97-1998/99) the efficacy was studied of Triticale as a nitrogen (N) catch crop sown after the harvest of the potato crop cultivated in the preceding summer season under several $\mathrm{N}$ fertilizer treatments. In October, shortly after the harvest of the potatoes, there were registered significative differences in the soil $\mathrm{N}-\mathrm{NO}_{3}^{-}$levels among $\mathrm{N}$ fertilizer treatments of the potato crop. The higher values were recorded on the plots corresponding to higher $\mathrm{N}$ doses. At the end of winter, the $\mathrm{N}$ status of plants and at the end of experiments (late in April), the $\mathrm{N}-\mathrm{NO}_{3}^{-}$in soil, the biomass yield and the $\mathrm{N}$ uptake by the catch crop did not reflect the differences registered before in the soil inorganic $\mathrm{N}$. This comparison may suggest that Triticale is little effective in recovering the residual inorganic $\mathrm{N}$ of the preceding crop due either to the rainfall occurring in the autumn or to the poor vegetative development of the catch crop during the autumn/winter period. However, at the date of cut, the catch crop removed up to $80 \mathrm{~kg} \mathrm{~N} \mathrm{ha}{ }^{-1}$. At this time, the soil $\mathrm{N}-\mathrm{NO}_{3}^{-}$levels were significantly higher on the fallowed plots. This result shows that the crop was very effective in uptaking the $\mathrm{N}$ that is mineralized after the end of winter.
\end{abstract}

Keywords: Soil residual N; Soil N reserves; N- and biomass yield; Rainfall

\section{Introduction}

The use of nitrogenous fertilizers in excess of $\mathrm{N}$-yield of arable crops is a common practice in some regions of Europe with high-input agriculture. There are several reasons for that, namely: (i) the low share of $\mathrm{N}$ in the production costs; (ii) some tendency for the growers to overestimate their yield goals (Rice and Havlin, 1994); and (iii) some uncertainty in the $\mathrm{N}$ fertilizer recommendations (Dahnke and Johnson, 1990). The use of $\mathrm{N}$ in higher amounts than crop needs is an important problem in so far as the excess can be leached during autumn and winter from the soils into surface- and ground-waters. The importance of the problem was recognized by the European Union that, in the ambit of nitrate directive (91/ $676 / \mathrm{CEE}$ ), promoted the creation of the code of good agricultural practice for the protection of water. 
Growing winter $\mathrm{N}$ catch crops between the summer crops can be one way to reduce the problem. Those crops can uptake the residual inorganic $\mathrm{N}$ present in soils at the end of the summer growing season as well as that, which will be mineralized during the following winter period, till the beginning of the next summer season. Many researchers have tried to get information about the use of different species (Jensen, 1992; Chapot and Robin, 1994; van Dam, 1994), the best cultural practices, particularly the date of sowing and ploughing of the catch crop (Thomsen, 1993; Chapot, 1994) or the effect of both factors (Vos and Putten, 1994; Allison et al., 1998). There has been a study, also; of the effect of $\mathrm{N}$ catch crops on the growth of succeeding crops (Martinez and Guiraud, 1990; Sørensen and Thorup-Kristensen, 1993), as well as the longterm effect of the continued incorporation of large amounts of plant biomass on $\mathrm{N}$ dynamic in soil (Lewan, 1994; Aronsson and Torstensson, 1998). The results obtained up to this time about the catch crops $\mathrm{N}$ recovery efficiency have been variable and seem to be dependent on the species, cultural practices and ecological conditions.

In farming and cattle raising in the North of Portugal it is usual to grow fodder crops in the autumn/winter season. These crops are sown early in the autumn and mowed in the next spring to feed the cattle. In this study the efficacy of Triticale as $\mathrm{N}$ catch crop was considered, taking into account that the summer is warm and dry and the sowing does not take place before the start of autumn rains. On the other hand, the transition to the winter is rapid and November is already a cold month, which limits the development of the crops until the end of the winter.

\section{Material and methods}

The experiments were conducted at Bragança in Northeast Portugal during the autumn/winter periods of $1996 / 97$ to $1998 / 99$. The soil of the experimental farm is classified as eutric cambisol (FAO). It is sandy loam textured, with $\mathrm{pH}_{\left(\mathrm{H}_{2} \mathrm{O}\right)}$ of 6.5 and an organic matter content of about $1.5 \%$. The region has a mediterranean climate with some atlantic influence (Gonçalves, 1985). The weekly values of the precipitation for the SeptemberApril period over the 3 years of the experiments are presented in Fig. 1.

The $\mathrm{N}$ catch crop was sown onto the experimental design of potato $\mathrm{N}$ fertilization trials that occurred in the preceding season. In those experiments five $\mathrm{N}$ doses were used $(0,50,100,200$ and $300 \mathrm{~kg} \mathrm{~N} \mathrm{ha}^{-1}$, as urea) which were applied at planting time. The trials had been organized as a randomized block design, with three replicates. By splitting each one of the former plots into two parts, there were constituted the treatments of the experiment reported here: a catch crop treatment and a control treatment (without a catch crop). The control treatment was obtained by applying a herbicide after the emergence of the plants. In this manner, there were established 15 pairs of plots, with and without plants, where in the preceding season there had been applied different $\mathrm{N}$ doses.

As a nitrogen catch crop Triticale (Triticosecale Wittm., cv. Misionero) was used. Sowing occurred on 20 October in 1996 and 23 January and 21 October in 1998. About 4-5 weeks after sowing dates, when the Triticale plants and a great number of weeds had emerged, the herbicide (30.8\% glyphosate acid equivalent) was applied in half of each plot area.
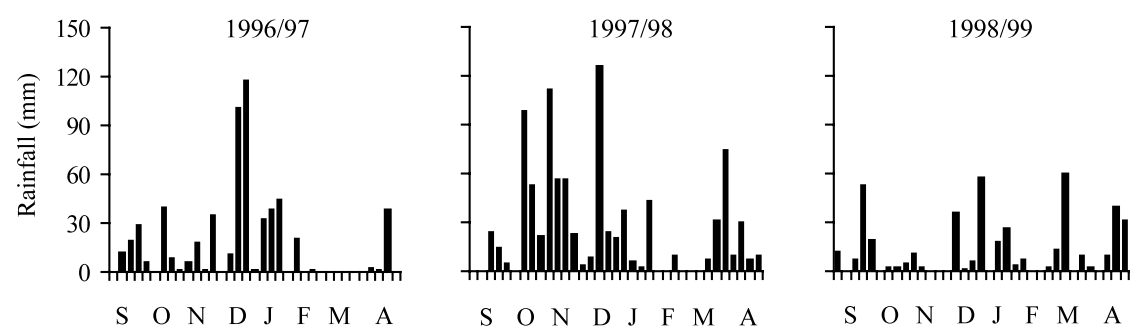

Fig. 1. Weekly cumulative rainfall from September to April for the years of the experiments. 

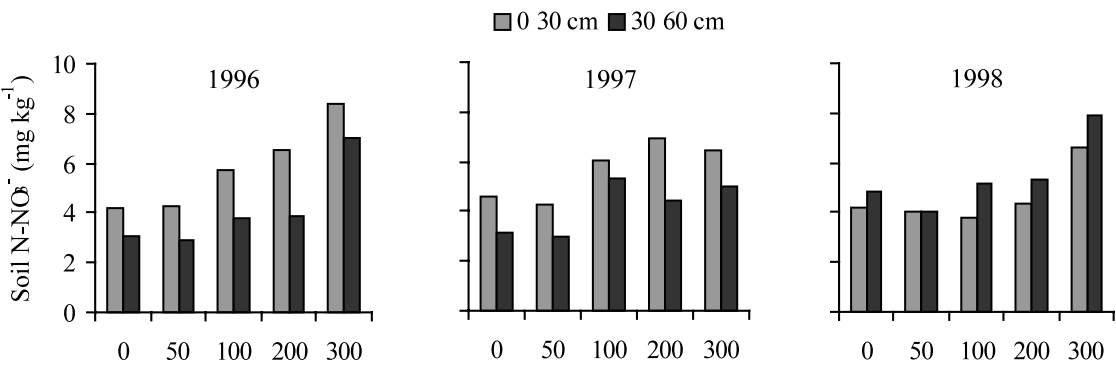

Preplant $\mathrm{N}$ applied on the potato crop $\left(\mathrm{kg} \mathrm{ha}^{-1}\right)$

Fig. 2. Soil $\mathrm{N}-\mathrm{NO}_{3}^{-}$content shortly after potato harvest.

In the early autumn, as soon as the potatoes were harvested, the soil was sampled to a depth of $60 \mathrm{~cm}$ divided into the layers $0-30$ and $30-60 \mathrm{~cm}$, to determine the amounts of inorganic $\mathrm{N}$ in the soil. In April, after the harvest of the Triticale, soil cores were taken using the same procedure, including now both the plots with and without crop. The subsamples from each plot and depth were mixed, to form composite samples, sieved ( 2 $\mathrm{mm}$ mesh size) and frozen until analysis was made. For analysis, $20 \mathrm{~g}$ of moist soil was extracted with $40 \mathrm{ml} 2 \mathrm{M} \mathrm{KCl}$, and the extracts were analyzed for $\mathrm{N}-\mathrm{NH}_{4}^{+}$and $\mathrm{N}-\mathrm{NO}_{3}^{-}$. The concentrations of $\mathrm{N}-\mathrm{NO}_{3}^{-}$were determined with the sulfanalamine method and the concentrations of $\mathrm{N}-\mathrm{NH}_{4}^{+}$by the Berthelot method (Houba et al., 1989). Both the ions were analyzed spectrophotometrically in an analyzer of segmented flow.

Close to the end of winter, at 22-23 growth stage of the decimal code of Zadoks et al., (1974), the $\mathrm{N}$ status of the Triticale crop was evaluated by measuring nitrate and $\mathrm{N}$ content in the above ground plant parts. About 60-70 randomly selected plants per plot were cut at $1 \mathrm{~cm}$ height from soil. Senescent and chlorotic leaves were excluded. Nitrate concentrations in extracts, prepared with representative samples of fresh tissues and distilled water, were analyzed by a quick procedure, using Reflectoquant test strips and the hand held RQflex reflectometer. The surplus plant material was dried $\left(65^{\circ} \mathrm{C}\right)$ and ground and its $\mathrm{N}$ concentration determined in Kjeldahl digests by a Kjeltec Auto 1030 analyzer.

The biomass yielded on the plots where the catch crop was grown (including the contribution of weeds) were cut on 24, 23 and 28 April in 1997, 1998 and 1999, respectively. Near to the center of the plots, in a $2 \mathrm{~m}^{2}$ area, the plants were cut at 5 $\mathrm{cm}$ height and the biomass of the samples weighed. For the determination of dry matter percentage and its $\mathrm{N}$ content subsamples with $600-800 \mathrm{~g}$ of biomass were used. The samples were dried and ground and the $\mathrm{N}$ content determined by the Kjeldahl method. Nitrogen recovery was calculated from the dry matter produced and its $\mathrm{N}$ content.

The effect of fertilizer treatments of the potato trial on inorganic $\mathrm{N}$ in soil, $\mathrm{N}$ status of Triticale plants, yielded biomass and $\mathrm{N}$ recovery was evaluated by analysis of variance. The means with significant differences $(\alpha<0.05)$ were separated by Fisher's LSD test. A pairwise $t$-test $(\alpha<0.05)$ was carried out to compare the inorganic $\mathrm{N}$ levels in soil under catch crop or bare soil.

\section{Results and discussion}

\subsection{Soil residual inorganic nitrogen at start of the autumn}

The effect of $\mathrm{N}$ fertilization treatments of the potato crop on residual inorganic $\mathrm{N}$ at the end of summer growing season is presented in Fig. 2. The amount of $\mathrm{N}-\mathrm{NO}_{3}^{-}$in the soil profile was closely related to the rate of $\mathrm{N}$ applied on the potato trials and the differences among $\mathrm{N}$ treatments had statistical significance in 1996 and 1998. The results showed that a great part of the $\mathrm{N}$ applied as fertilizer was not recovered by the 
plants. That can be justified by the poor $\mathrm{N}$ use efficiency of the potato crop (Rodrigues and Coutinho, 1996).

Soil $\mathrm{N}-\mathrm{NO}_{3}^{-}$values were higher in the upper layer, except in 1998 (Fig. 2). Accepting that the nitrates are formed predominantly in the more aired shallow soil, from organic matter by ammonification and nitrification, the result of 1998 can be justified by the heavy rainfall (more than $50 \mathrm{~mm}$ ) which occurred shortly before the soil cores were taken. The result stresses the start of the process of nitrate leaching to deeper layers.

\subsection{Nitrogen nutrition status of the crop during the winter}

The results regarding the $\mathrm{N}$ nutrition status of the crop during the winter are presented in Table 1. Significant differences were found in $\mathrm{N}$ content of plants in 1999. When the index used was the $\mathrm{N}-\mathrm{NO}_{3}^{-}$content of plants, there were not differences in the results for any of the years. The lack of significancy among N treatments in 1997 and 1998 for both the indices is attributed to nitrate leaching and/or denitrification, due to the great cumulative rainfall registered in the autumn/winter period of these years (Fig. 1). On the contrary, the extremely dry autumn/winter period of 1998/ 99 permitted significant differences to be found in the N status of plants in February of 1999. The rainfall of the wet season is often used to justify differences of the residual inorganic $\mathrm{N}$ value among growth seasons or regions (van der Paauw, 1963).
The result gives supplemental information about the sensitivity of the $\mathrm{N}$ nutrition indices. The $\mathrm{N}$ content in above ground biomass seems to be a more suitable index than the $\mathrm{N}-\mathrm{NO}_{3}^{-}$. The latest is usually recommended when conductive tissues, like petioles or stems, are available (Mills and Jones, 1996), which do not occur with the Triticale at this growth stage.

\subsection{Catch crop biomass and $N$ uptake}

Results of biomass yielded, $\mathrm{N}$ content of dry matter and $\mathrm{N}$ removed by the catch crop at the end of the experiments are presented in Table 2. The average values of the above-mentioned parameters did not differ among treatments in 1997 and 1998. Results with statistical significance were only recorded in 1999 for the above ground biomass. In this case, the treatments respecting to large amounts of $\mathrm{N}$ applied one year before originated the higher yields. The results are in accordance with the indication given by the $\mathrm{N}$ status of plants.

The yielded biomass on the plots with catch crop was greater in 1999 than in the previous years. In 1997 the yield was reduced by the extreme dryness of the spring (Fig. 1). In 1998 it was the sowing date which was the most important factor that compromized the yield. In this year, the rainfall of the autumn/winter period did not permit the sowing of the catch crop before 23 January. The intense cold of this time made the normal emergence of the plants difficult, which seriously affected the biomass produced.

Table 1

Effect of $\mathrm{N}$ fertilizer treatments of the potato trials on nitrate and $\mathrm{N}$ content of the above ground part of Triticale at the end of winter

\begin{tabular}{|c|c|c|c|c|c|c|}
\hline \multirow[t]{2}{*}{$\mathrm{N}$ applied $\left(\mathrm{kg} \mathrm{ha}^{-1}\right)$} & \multicolumn{3}{|c|}{$\mathrm{N}\left(\mathrm{g} \mathrm{kg}^{-1}\right)$} & \multicolumn{3}{|c|}{ Nitrates $\left(\mathrm{mg} \mathrm{N}-\mathrm{NO}_{3}^{-} \mathrm{kg}^{-1}\right)$} \\
\hline & 1997 & 1998 & 1999 & 1997 & 1998 & 1999 \\
\hline 0 & 2.86 & 2.92 & $3.02 \mathrm{c}^{*}$ & 93.3 & 44.7 & 74.6 \\
\hline 50 & 3.03 & 3.11 & $3.39 b$ & 129.4 & 116.5 & 63.7 \\
\hline 100 & 2.80 & 3.08 & $3.44 \mathrm{ab}$ & 87.5 & 108.4 & 47.0 \\
\hline 200 & 2.91 & 2.95 & $3.60 \mathrm{ab}$ & 129.9 & 98.7 & 128.0 \\
\hline \multirow[t]{2}{*}{300} & 2.77 & 2.99 & $3.90 \mathrm{a}$ & 102.9 & 113.8 & 194.1 \\
\hline & ns & ns & & $\mathrm{ns}$ & $\mathrm{ns}$ & $\mathrm{ns}$ \\
\hline
\end{tabular}

\footnotetext{
*, In columns, means with the same letter do not differ by Fisher's LSD test $(\alpha<0.05)$; ns, not significative.
} 
Table 2

Effect of $\mathrm{N}$ treatments of the potato crop on dry matter yield, $\mathrm{N}$ content on dry matter and $\mathrm{N}$ recovered of Triticale at the end of April

\begin{tabular}{|c|c|c|c|c|c|c|c|c|c|}
\hline \multirow[t]{2}{*}{$\mathrm{N}$ applied $\left(\mathrm{kg} \mathrm{ha}^{-1}\right)$} & \multicolumn{3}{|c|}{ Dry matter $\left(\mathrm{mg} \mathrm{ha}^{-1}\right)$} & \multicolumn{3}{|c|}{$\mathrm{N}$ content $\left(\mathrm{g} \mathrm{kg}^{-1}\right)$} & \multicolumn{3}{|c|}{$\mathrm{N}$ recovered $\left(\mathrm{kg} \mathrm{ha}^{-1}\right)$} \\
\hline & 1997 & 1998 & 1999 & 1997 & 1998 & 1999 & 1997 & 1998 & 1999 \\
\hline 0 & 2.92 & 0.89 & $4.75 c^{*}$ & 10.2 & 15.6 & 9.6 & 29.1 & 13.9 & $45.6 \mathrm{c}$ \\
\hline 50 & 3.56 & 1.54 & $6.33 \mathrm{abc}$ & 9.3 & 16.8 & 10.4 & 33.2 & 26.2 & $65.5 \mathrm{ab}$ \\
\hline 100 & 3.84 & 1.59 & $5.64 \mathrm{bc}$ & 9.4 & 16.4 & 10.0 & 35.3 & 26.1 & $56.3 \mathrm{bc}$ \\
\hline 200 & 4.68 & 1.56 & $7.07 \mathrm{ab}$ & 9.3 & 17.3 & 10.2 & 43.0 & 26.9 & $72.1 \mathrm{ab}$ \\
\hline \multirow[t]{2}{*}{300} & 3.62 & 1.20 & $7.29 \mathrm{a}$ & 9.4 & 17.4 & 10.9 & 34.0 & 20.6 & $79.6 \mathrm{a}$ \\
\hline & ns & ns & & ns & ns & ns & ns & ns & \\
\hline
\end{tabular}

*, In columns, means with the same letter do not differ by Fisher's LSD test $(\alpha<0.05)$; ns, not significative.
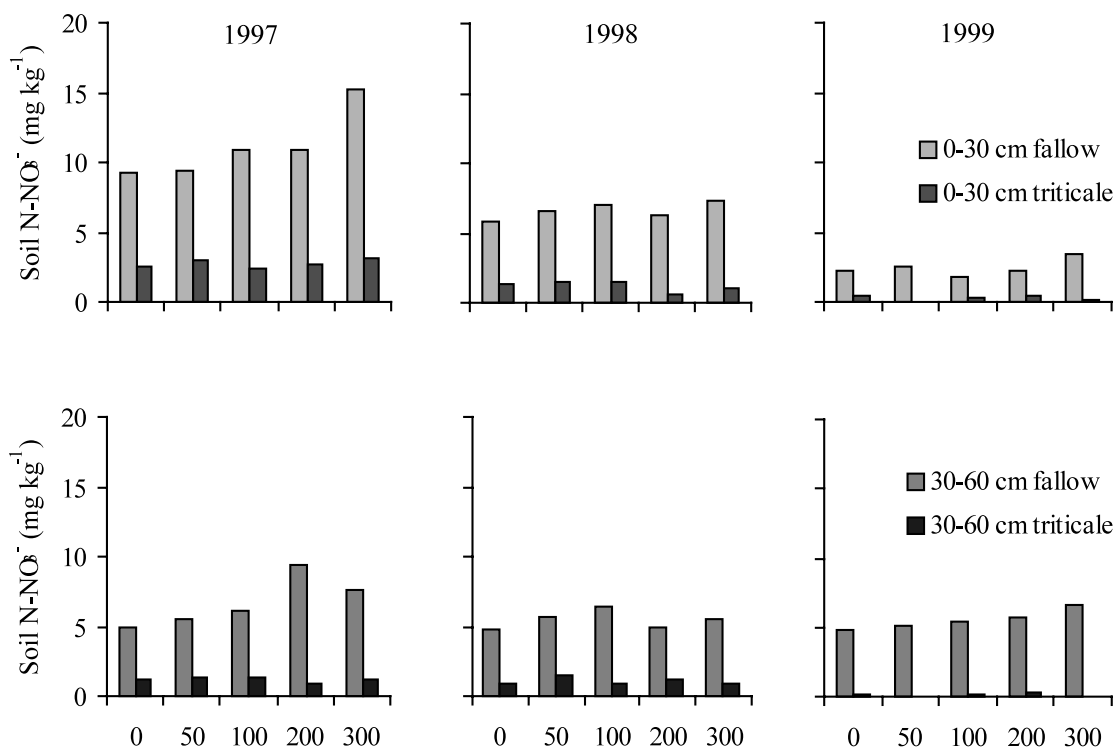

Preplant $\mathrm{N}$ applied on the potato crop $\left(\mathrm{kg} \mathrm{ha}^{-1}\right)$

Fig. 3. Values of $\mathrm{N}-\mathrm{NO}_{3}^{-}$in soil at the end of April on the plots with and without the catch crop.

The values of $\mathrm{N}$ content of plants in 1999 were greater than the 1997 and 1998 ones. The result is attributed to the floristic composition of the biomass analyzed. In 1999, due to the problems on the catch crop emergence, the biomass was dominated by weeds, that had grown in the absence of the catch crop. The results of $\mathrm{N}$ uptaken by the catch crop reflected the differences in the biomass produced, now that the $\mathrm{N}$ content of plants was similar for all the treatments. The values of $\mathrm{N}$ uptaken ranged between 13.9 and
$79.6 \mathrm{~kg} \mathrm{ha}^{-1}$, for the control treatment of 1997 and $300 \mathrm{~kg} \mathrm{~N} \mathrm{ha}{ }^{-1}$ for the treatment of 1999 , respectively.

\subsection{Soil residual inorganic nitrogen in April}

The levels of $\mathrm{N}-\mathrm{NO}_{3}^{-}$and $\mathrm{N}-\mathrm{NH}_{4}^{+}$in the soil profile in April did not differ significantly among treatments, either comparing the values in the fallowed or in the cropped plots (Fig. 3). The results showed that even in the absence of plants 
the inorganic $\mathrm{N}$ that had been found in the soil at the start of the autumn disappear during the winter, due to nitrate leaching and/or denitrification.

The $\mathrm{N}-\mathrm{NO}_{3}^{-}$values on topsoil $(0-30 \mathrm{~cm})$ in 1997 were greater than the values of the years that followed; mainly than the 1999 ones. The dryness of the end of winter and beginning of spring period in 1997 justify these results. In 1999 the proper development of the catch crop was also important, which contributed to the reduction of the soil $\mathrm{N}-\mathrm{NO}_{3}^{-}$levels.

To compare the levels of inorganic $\mathrm{N}$ in soil on the treatments with and without catch crop the pairwise $t$-test $(\alpha<0.05)$ was employed. The soil levels of $\mathrm{N}-\mathrm{NO}_{3}^{-}$on the cropped plots were significantly lower on the bare soil, for both the $0-30$ and 30-60 cm layers (Fig. 3). This result makes evident the great capacity of the catch crop to uptake the $\mathrm{N}$ mineralized during the end of winter and in the early spring period.

The soil $\mathrm{N}-\mathrm{NH}_{4}^{+}$levels at April did not differ either among fertilizer treatments or between the systems of ground cover. The levels of $\mathrm{N}-\mathrm{NH}_{4}^{+}$in soil were not inferior in the plots with plants compared to the uncropped soils. This result demonstrates the great dynamism of the $\mathrm{NH}_{4}^{+}$in these soils and provides enough evidence that microorganisms are the most important users of this $\mathrm{N}$ form, as was suggested by Recous et al., (1988), at least when the levels of the ion in soil are low. The mechanisms involved must be nitrification and biological immobilization.

\section{References}

Allison, M.F., Armstrong, M.J., Jaggard, K.W., Todd, A.D., 1998. Integration of nitrate cover crop into sugarbeet (Beta vulgaris) rotations. I. Management and effectiveness of nitrate cover crops. J. Agric. Sci. (Cambridge) 130, 53-60.

Aronsson, H., Torstensson, G., 1998. Measured and simulated availability and leaching of nitrogen associated with frequent use of catch crops. Soil Use and Management 14, $6-13$.

Chapot, J.-Y., 1994. Effect of cover crop, between wheat and maize on nitrate leaching and drainage. Lysimeter study on two soil texture types. Proc. 3rd Congress of the European Society for Agronomy. Abano-Padova, Italy, 776-777.
Chapot, J.-Y., Robin, P., 1994. Comparison of nitrogen uptake potential of six non leguminous cover crops after wheat. Estimate of some parameters of nitrate uptake. Proc. 3rd Congress of the European Society for Agronomy. AbanoPadova, Italy, 778-779.

Dahnke, W.C., Johnson, G.V., 1990. Testing soils for available nitrogen. In: Westerman, R.L. (Ed.), Soil Testing and Plant Analysis Book Series no. 3, vol. SSSA, 3rd ed, pp. 127-139.

Gonçalves, D.A., 1985. Contribuição para o estudo do clima da bacia superior do rio sabor. Ph. D. Thesis, IUTAD, Vila Real.

Houba, V.J., van der Lee, J.J., Novozamsky, I., Walinga, I., 1989. Soil and Plant Analysis. Part 5-Soil Analysis Procedures. Wageningen.

Jensen, E.S., 1992. The release and fate of nitrogen from catch-crop materials decomposing under field conditions. J. Soil Sci. 43, 335-345.

Lewan, L., 1994. Effects of catch crop on leaching of nitrogen from a sandy soil: simulations and measurements. Plant Soil $166,137-152$.

Martinez, J., Guiraud, G., 1990. A lysimeter study of the effects of a ryegrass catch crop, during a winter wheat/maize rotation, on nitrate leaching and on the following crop. J. Soil Sci. 41, 5-16.

Mills, H.A., Jones, J.B., 1996. Plant Analysis Handbook. MicroMacro Publishing, GA, USA.

Recous, R., Machet, J.M., Mary, B., 1988. The fate of labelled ${ }^{15} \mathrm{~N}$ urea and ammonium nitrate applied to a winter wheat crop. Plant Soil 112, 215-224.

Rice, C.W., Havlin, J.L., 1994. Integrating mineralizable nitrogen indices into fertilizer nitrogen recommendation. In: Havlin, J.L., Jacobsen, J.S. (Eds.), Soil Testing: Prospects For Improving Nutrient Recommendations, vol. SSSA, pp. 1-13 Spec. Publ. No. 40.

Rodrigues, M.A., Coutinho, J., 1996. Efficiency of uptake and utilization of $\mathrm{N}$ from mineral and organic sources by potato crop. Proc. 4th Congress of the European Society for Agronomy. Veldhoven-Wageningen, The Netherlands, $368-369$.

Sørensen, J.N., Thorup-Kristensen, K., 1993. Nitrogen effects of non-legume catch crops. Z. Pflanzenernähr. Bodenk 156, $55-59$.

Thomsen, I.K., 1993. Nitrogen uptake in barley after spring incorporation of ${ }^{15} \mathrm{~N}$-labeled italian ryegrass into sandy soils. Plant Soil 150, 193-201.

van Dam, A.M., 1994. Photosynthesis in catch crops during autumn and winter in relation to nitrogen supply. Proc. 3rd Congress of the European Society for Agronomy. AbanoPadova, Italy, 264-265.

van der Paauw, F., 1963. Residual effect of nitrogen fertilizer on succeding crops in a moderate marine climate. Plant Soil XIX (3), 324-331.

Vos, J., Putten, P., 1994. Nitrogen accumulation in catch crops. Proc. 3rd Congress of the European Society for Agronomy. Abano-Padova, Italy, 846-847.

Zadoks, J.C., Chang, T.T, Konzak, C.F., 1974. A decimal code for the growth stages stages of cereals. Weed Res. 14, $415-421$. 